\title{
TANGGUNG GUGAT NOTARIS ATAS KELALAIAN DALAM MEMBUAT AKTA PERJANJIAN KREDIT BANK
}

\author{
RYNO BAGAS PRAHARDIKA* \\ ENDANG SRI KAWURYAN \\ Kantor Notaris Nunuk Endang Purwaningsih, SH, MH \\ Jalan Gatot Subroto No. 146, Mrican, Kediri \\ Email : rynobagas@yahoo.co.id
}

\begin{abstract}
ABSTRAK
Notaris merupakan pejabat umum yang berhak untuk membuat akta otentik sejauh pembuatan akta otentik tersebut tidak dikhususkan bagi pejabat umum lainnya karena Notaris diangkat oleh pemerintah khusus untuk pembuatan akta tersebut.Akta Otentik dibuat berdasarkan kepentingan para pihak guna mendapatkan alat bukti yang sempurna yang nantinya dapat dijadikan sebagai suatu alat bukti apabila terjadi sengketa antara pihak-pihak yang berkepentingan. Selain pembuatannya yang berdasarkan atas permintaan para pihak akta otentik juga dibuat berdasarkan peraturan perundang-undangan yang berlaku.Semua akta yang dibuat oleh Notaris mempunyai nilai pembuktian yang sempurna dihadapan hukum sehingga jika ada yang meragukan akta tersebut maka harus dibuktikan sebaliknya dalam Pengadilan. Walaupun Notaris mempunyai hak untuk membuat akta otentik, namun apabila dalam pembuatan akta tersebut tidak memenuhi unsur-unsur dalam Tehnik Pembuatan Akta atau yang telah ditentukan oleh Undang-undang dan dapat merugikan para pihak maka notaris dapat digugat.Penelitian ini dikualifikasikan sebagai penelitian hukum normatif, dengan menggunakan pendekatan perundangundangan dan pendekatan konseptual.Bahan hukum yangdipergunakan dalam penelitian ini berasal dari hasil penelitian kepustakaan berupa bahanhukum primer, dan bahan hukum sekunder.kemudian dikelompokkan dan dikaji dengan pendekatan perundang-undangan guna memperoleh gambaran sinkronisasi dari semua bahan hukum. Selanjutnya dilakukan sistematisasi dan klasifikasi kemudian dikaji serta dibandingkan dengan teori dan prinsip hukum yang dikemukakan oleh para ahli, untuk akhirnya dianalisa secara normatif.Hasil penelitian ini menunjukkan bahwa sebagai akibat hukum darikelalaianterhadap pembuatan akta otentik maka Notaris dapatdikenai sanksi sebagai wujud pertanggungjawaban dan tanggung gugatNotaris secara perdata danadministratif dari organisasi Notaris. Sedangkan untuk proses pemanggilan notaris yang ditengarai melakukan perbuatan melawan hukum diatur dalam Permenkumham Nomor 7 tahun 2016 tentang Majelis Kehormatan Notaris.
\end{abstract}

Kata Kunci : Kewenangan Notaris, Sanksi Notaris, Peran Majelis Kehormatan Notaris 


\section{LATAR BELAKANG MASALAH}

Notaris oleh undang-undang diberi wewenang untuk menuangkan semuaperbuatan, perjanjian dan penetapan yang dikehendaki oleh pihak atau pihakpihakyang sengaja datang kehadapan Notaris untuk mengkonstatir keterangan itu dalamsuatu akta otentik, dan agar akta yang dibuatnya itu memiliki kekuatan bukti yanglengkap dan memiliki keabsahannya ${ }^{1}$

Menurut Pasal 1 ayat (1) Undang-undang Jabatan Notaris Nomor 2 Tahun 2014, atas perubahan Undang-undang Nomor 30 Tahun 2004 (untuk selanjutnya disebut UUJN) yang berbunyi:

"Notaris adalah Pejabat U mum yang berwenang untuk membuat akta autentik dan memiliki wewenang lainnya sebagaimana dimaksud dalam Undangundang ini atau berdasarkan undang-undang lainnya" .

Adanya bunyi pasal ini begitu penting bagi masyarakat, dimana saat ini semua kegiatan masyarakat membutuhkan kepastian hukum sebagai alat bukti jika terjadi masalah dikemudian hari dalam bentuk tertulis.

Menurut Setiawan,tugas penting seorang notaris ialah "mengatur secaratertulis dan autentik hubungan hukum antara pihak yang secara manfaat meminta jasanotaris yang pada dasarnya adalah sama dengan tugas hakim yang memberikankeadilan diantara para pihak yang bersengketa". ${ }^{2}$ Hal ini juga senada dengan Pasal 15 ayat (1) UUJN

Peranan Notaris, di dalam kehidupan masyarakat ataupun berbisnis sangatlah dibutuhkan, baik dalam hal membuat perjanjian, membuat sewa menyewa, maupun jual beli tanah. Salah satu bisnis yang sangat memerlukan jasa seorang notaris adalah dunia perbankan. Dimana dalam dunia perbankan notaris dibutuhkan untuk membuat suatu akta perjanjian kredit antar nasabah dengan bank ketika nasabah sedang mengambil kredit di bank.

Akta otentik tersebut dibuat berdasarkan keinginan para pihak yang hadir bersama-sama dihadapan notaris dan meminta kepada notaris untuk membuat suatu

${ }^{1}$ Suhardjono, Sekilas Tinjauan Akta Menurut Hukum, Varia Peradilan, Nomor 123, 1995, hlm.133-135

${ }^{2}$ Setiawan Wawan, Hak Ingkar dari Notaris dan Hubungannya dengan KUHAP (suatu kajian uraian yang disajikan dalam konggress INI di Jakarta, 1995), hlm. 2. 
alat bukti tertulis sebagai pegangan para pihak apabila nanti terjadi sengketa dikemudian hari, sehingga dapat dijadikan sebagai alat bukti. Atas keinginan dan maksud tersebut dan dengan berdasarkan keterangan dan syarat yang sudah ditentukan, kemudian notaris menuangkan keinginan para pihak tersebut kedalam akta otentik.

Akta yang dibuat oleh Notaris merupakan akta yang tidak perlu diragukan lagi kebenarannya sehingga harus memiliki unsur kesempurnaan atau harus sesuai dengan UUJN, dengan demikianseorang Notaris memiliki beban moral dan tanggung jawab yang besar atas akta yang telah dibuatnya tersebut.

Namun apabila akta yang dibuat tersebut ternyata tidak sesuai dengan draft yang diberikan oleh bank kepada notaris atau tidak sesuai dengan offering latter, dimana hal tersebut bisa menimbulkan kerugian baik terhadap pihak Debitor maupun Kreditur, maka notaris dapat digugat atas kelalaiannya tersebut, dan bisa dikenai sanksi ganti rugi yang telah dialami oleh para pihak.

Jika akta yang telahdibuat tidak seperti peraturan perundang-undangan yang berlaku, maka akta tersebutakan cacat secara yuridis dan mengakibatkan akta tersebut terdegradasiatau batalnya akta tersebut.

Pihak Bank biasanya dalam melakukan pencairan kredit, terlebih dahulu akan memberikan form berupa penawaran terhadap calon debitur yang berkaitan dengan besarnya jumlah pinjaman, angsuran, dan tenor terhadap calon debitornya, jika debitur tersebut menyetujui maka setelah itu bank dan calon debitur datang dihadapan notaris untuk menandatangani perjanjian kredit yang yang dibuat oleh notaris.Perjanjian kredit ini merupakan bentuk hubungan hukum yang berkelanjutan antara Debitur dengan Kreditur (dalam hal ini Bank) yang melahirkan hubungan hutang piutang dalam jangka waktu tertentu, dimana debitur berkewajiban membayar kembali seluruh pinjaman yang telah diberikan oleh Kreditur, berdasarkan syarat dan kondisi yang telah disepakati oleh para pihak.

Akta perjanjian kredit Bank yang dibuat oleh notaris ini merupakan, Akta para pihak atau Partij Acten, dimaksudkan sebagai akta yang dibuat oleh dandihadapan notaris yang berisi uraian atau keterangan, pernyataan para pihak yangdiberikan atau diceritakan di hadapan notaris. Para pihak berkeinginan agar uraian atau 

keterangannya dituangkan kedalam bentuk Akta Notaris.Atas Akta jenis inidiantaranya adalah akta jual beli, akta sewa menyewa, akta Perjanjian Kredit dansebagainya. ${ }^{3}$

Jika dilihat dari pembuatannya, suatu perjanjian kredit dapat digolongkan menjadiPerjanjian Kredit dibawah tangan, yaitu perjanjian kredit yang dibuat oleh antara para pihak yang terlibat dalam perjanjian kredit tersebut tanpa melibatkan pihak pejabat yang berwenang (notaris), dan Perjanjian Kredit Notariil yaitu perjanjian yang dibuat dan ditandatangani oleh para pihak di hadapan Notaris, sehingga merupakan akta yang bersifat otentik (dibuat oleh dan di hadapan pejabat yang berwenang / Notaris). ${ }^{4}$

Mengenai isi pasal atau klausul-klausul yang digunakan oleh bank dalam perjanjian kredit, sebenarnya sampai sekarang bank tidak mempunyai acuan umum tentang hal tersebut, namun biasanya bank mempercayakan hal tersebut kepada notaris tentang isi pasal atau klausul-klausul yang akan digunakan untuk mengikat nasabah dalam pemberian kredit. Dalam hal penentuan isi pasal dan klausul dalam perjanjian kredit, kedudukanbank sebagai kreditor selalu lebih diuntungkan daripada nasabah sebagai debitor.Posisi bank selalu lebih kuat dari nasabah (debitor, dalam hal nasabah (debitor) termasuk pengusahaekonomilemah ${ }^{5}$. Misalnya sebelum perjanjian kredit ditandatangani, debitur meminta suku bunga diturunkan atau jumlah angsuran diturunkan sesuai kemampuan debitur tetapi ditolak oleh pihak bank yang terkadang suku bunga dan angsuran tersebut sangat memberatkan debitur, namun karena posisi debitur saat pengajuan kreditsangat membutuhkan uang tersebut, maka mau tidak mau mereka setuju saja dengan semua ketentuan yang ditetapkan oleh pihak bank, atau contoh lainnya adalah pihak bank (kreditur) berhak menaikkan suku bunga kredit tanpa terlebih dahulu melakukan kesepakatan dengan pihak debitur padahal diawal perjanjian sudah disepakati suku bunga yang telah disetujui oleh debitur hal ini tentu saja debitur sangat dirugikan atas kebijakan tersebut.

3 G.H.S. Lumban Tobing, Peraturan Jabatan Notaris, Cetakan ke-5, Jakarta : Erlangga, hlm.51-52

${ }^{4}$ Learning about Indonesian Legal Banking

${ }^{5}$ Sutan Remi Sjahdeini, Kebebasan Berkontrak dan Perlindungan yang Seimbang bagi Para Pihak dalam Perjanjian Kredit Bank di Indonesia, Cetakan I, Institut Bankir Indonesia, Jakarta, 1993, hlm. 2-3 

Suatu perjanjian bisa dikatakan sah dan berlaku bagipara pihak yang membuat perjanjian apabila perjanjian itu sudahmemenuhi ketentuan-ketentuan yang diatur dalam Pasal 1320 KUHPerdata,antara lain sebagai berikut:

1. Kata sepakat yang membuat perjanjian;

2. Kecakapan pihak-pihak yang melakukanperjanjian;

3. Obyek perjanjian itu harus jelas;

4. Perjanjian itu dibuat atas dasar suatusebab yangdiperbolehkan

Dalam ilmu hukum dikenal 3 (tiga) kategori dari perbuatan melawan hukum, yaitu sebagai berikut ${ }^{6}$ :

1. Perbuatan melawan hukum karenakesengajaan

2. Perbuatan melawan hukum tanpakesalahan (tanpa unsur kesengajaan maupunkelalaian)

3. Perbuatan melawan hukum karena kelalaian

Menurut Munir Fuady $^{7}$, suatu perbuatan dapat dianggap sebagaisuatu kelalaian, jika memenuhi unsur-unsur pokok sebagai berikut :

1. Adanya suatu tindakan yangmengakibatkan hal yang tidak semestinyadilakukan

2. Adanya suatu kewajiban kehati-kehatian

3. Tidak dijalankan kewajiban kehati-hatiantersebut

4. Adanya kerugian bagi orang lain

5. Adanya hubungan sebab akibat antaraperbuatan dengan kerugianyang timbul.

\section{Rumusan Masalah}

1. Apa akibat hukum terhadap akta perjanjian kredit yang dibuat karena adanya kelalaian notaris dalam pembuatannya terhadap para pihak?

2. Apa bentuk tanggung gugat Notaris atas kelalaiannya terhadap Akta Otentik yang dibuat oleh atau dihadapannya? 


\section{Landasan Teoritis}

\section{Teori Jabatan}

Jabatan diartikan juga sebagaitugas atau kedudukan yang diberikan kepada seseorang dimana tugas atau kedudukan tersebut dapat menggambarkan tanggung jawab dan wewenang seseorang dalam suatu pekerjaan tertentu. Dalam pemberian jabatan ini tidak serta merta diberikan terhadap semua orang namun dalam hal jabatan ini dibutuhkan seseorang yang benar-benar mempunyai pengetahuan, keterampilan, dan kemampuan yang baik untuk menunjang dalam hal pemberian jabatan tersebut. Menurut Logemann :

"Jabatan adalah lingkungan pekerjaan tetap yang digaris batasi dan yang disediakan untuk ditempati oleh pemangku jabatan yang ditunjuk dan disediakan untuk diwakili oleh mereka sebagai pribadi.Berdasarkan hukum tata negara jabatanlah yang dibebani dengan kewajiban, yang berwenang untuk melakukan perbuatan hukum.Hak dan kewajiban berjalan terus, tidak terpengaruh dengan pergantian pejabat". 8

\section{Teori Wewenang}

Teori wewenang ini dikemukakan dengan tujuan untuk membahas dan menganalisa masalah tentang sejauh mana wewenang seseorang dalam menjalankan pekerjaannya ketika seseorang tersebut memangku suatu jabatan yang telah diberikan sehingga tidak merugikan orang lain. Habib Adjiemenyatakan, "Kewenangan merupakan suatu tindakan hukum yang diatur dan diberikan kepada suatu jabatan berdasarkanperaturan perundang-undangan yang berlaku yang mengatur jabatan yang bersangkutan",

\section{Teori Pertanggungjawaban}

Pertanggungjawaban dalam suatu tindakan hukum sangatlah diperlukan agar pejabat yang berwenang tidak sembarangan dalam pembuatan perjanjian, Ridwan H.RMenyatakan:

\footnotetext{
${ }^{8}$ Ridwan HR. 2006. Hukum Administrasi Negara. Jakarta : Raja Grafindo Persada. hlm.79

${ }^{9}$ Habib Adjie. 2009. Hukum Notaris Indonesia Tafsir Tematik Terhadap UU no.30 tahun 2004 Tentang Jabatan Notaris, cet. Kedua. Bandung: PT Refika Aditama. hlm. 77
} 

“Ada dua istilah yang menunjuk pada pertanggungjawaban dalam kamus hukum, yaitu liability dan responsibility.Liability merupakan istilah hukum yang luas yang menunjuk hampir semua karakter risiko atau tanggung jawab, yang pasti, yang bergantung atau yang mungkin meliputi semua karakter hak dan kewajiban secara aktual atau potensial seperti kerugian, ancaman, kejahatan, biaya atau kondisi yang menciptakan tugas untuk melaksanakan undangundang. Responsibility berarti hal yang dapat dipertanggungjawabkan atas suatu kewajiban, dan termasuk putusan, keterampilan, kemampuan dan kecakapan meliputi juga kewajiban bertanggung jawab atas undang-undang yang dilaksanakan.Dalam pengertian dan penggunaan praktis, istilah liability menunjuk pada pertanggungjawaban hukum, yaitu tanggung gugat akibat kesalahan yang dilakukan oleh subyek hukum, sedangkan istilah responsibility menunjuk pada pertanggungjawaban politik". ${ }^{10}$

\section{Metode Penelitian}

4.1. Penelitian ini merupakan suatu penelitian hukum normatif dengan menitikberatkan terhadapsampai sejauh mana tugas dan wewenang suatu jabatanyang telah diberikan khususnya terhadap notaris dalam hal pembuatan akta otentik dan sejauh mana tanggung gugat notaris bila terjadi kesalahan akibat kelalaian notaris dalam pembuatan akta otentik tersebut. Peter Mahmud Marzuki menyatakan bahwa penelitian hukum merupakan proses untuk menemukan aturan hukum, prinsip-prinsip hukum, maupun doktrin-doktrin hukum guna menjawab isu hukum yang dihadapi. ${ }^{11}$

\subsection{Pendekatan Masalah}

Pendekatan yang digunakan dalam penelitian hukum ini adalah pendekatan perundang-undangan (statue approach), pendekatan konseptual (conceptual

approach), ${ }^{12}$.

${ }^{10}$ Ibid., hlm. 335-337

${ }^{11}$ Peter Mahmud Marzuki, Penelitian Hukum, Cet. 6, Kencana Prenada Media Group, Jakarta, 2010, hlm.35

12 Johnny Ibrahim, Teori dan Metodologi Penelitian Hukum Normatif, Cet.3, Bayumedia, Malang, 2010, hlm.93

Ryno Bagas Rahardika, Endang Sri Kawuryan, Tanggung Gugat Notaris Atas .... 43 

Pendekatan perundang-undangan (statue approach) dilakukan dengan melihat semua peraturan perundang-undangan yang berkaitan dengan penelitian ini guna dijadikan dasar dalam menentukan sampai sejauh mana bentuk tanggung gugat notaris dalam hal kelalaiannya sehingga menimbulkan kerugian terhadap salah satu pihak. Pendekatan perundang-undangan diperlukan guna mengkaji lebih lanjut sejauh mana kewenangan dan tanggung jawab yang diberikan oleh undang-undang dalam pembuatan akta otentik. Dalam penelitian ini, perundang-undangan yang akan digunakan adalah Undang-undang Jabatan Notaris Nomor 2 Tahun 2014, atas perubahan Undang-undang Nomor 30 Tahun 2004, dan berbagai undang-undang lain yang mengatur tentang kewenangan dan tanggung gugat notaris atas kelalaiannya dalam pembuatan akta perjanjian kredit.

Pendekatan konseptual (conceptual approach), digunakan untuk mengkaji dan menganalisis kerangka pikir atau kerangka konseptual maupun landasan teoritis sehingga dapat ditemukan konsep atau teori baru sesuai dengan tujuan penelitian ini yakni menemukan jawaban atas permasalahan notaris tentang sejauhmana tanggung gugat notaris ketika terdapat salah ketik pada akta otentik yang dibuatnya sehingga merugikan salah satu pihak, menjelaskan dan menemukan tolok ukur sampai sejauh mana tanggung gugat seorang notaris ketika akta perjanjian kredit yang dibuatnya ada permasalahan secara tepat dan menemukan prinsip baru dalam menentukan sejauh mana tanggung gugat notaris atas kelalainnya dalam pembuatan akta perjanjian kredit bank. Isu hukum dan rumusan masalah tersebut diatas kemudian akan dianalisis dengan konsep dan teori-teori hukumyang ada. Dengan adanya Analisis terhadap konsep dan teori-teori hukum yang ada diharapkan dapat menghasilkan teori-teori baru yang berkaitan dengan tanggung gugat notaris atas kelalaian dalam pembuatan akta perjanjian kredit bank. Oleh karena itu teori yang digunakan nantinya adalah teori-teori tentang bentuk tanggung gugat terhadap suatu jabatan tertentu yang atas kelalaiannya dalam menjalankan jabatannya menimbulkan kerugian terhadap pihak lain. 



\section{Pembahasan}

\subsection{Akibat Hukum Terhadap Akta Perjanjian Kredit yang Dibuat}

KarenaAdanya Kelalaian Notaris Dalam Pembuatannya Terhadap Para Pihak.

Lalai dapat diartikan sebagai suatu tindakan yang dilakukan karena kurang berhati-hati dan mengakibatkan kerugian terhadap pihak lain. Bentuk kelalaian yang dilakukan oleh notaris ada berbagai macam, salah satunya adalah salah ketik atau salah tulis dalam pembuatan akta otentik yang karena hal tersebut dapat mengakibatkan akta tersebut nilai pembuktiannya menjadi tidak sempurna. Walaupun sebenarnya tanggung jawab notaris hanyalah di awal dan akhir akta namun notaris juga harus bertanggung gugat terhadap kebenaran materiilatas akta yang telah dibuatnya

Mengenai isi akta yang cacat hukum karena kelalaian yang dilakukan notaris sebenarnya sudah diatur dalam Pasal 48 UUJN, yang mana arti dalam pasal ini adalah Notaris ketika membuat suatu akta otentik dan apabila ada perubahan pada isi akta, notaris tidak berhak langsung merubah isi akta tersebut. Maksut dari merubah ini adalah notaris tidak boleh mengganti, menambah, mencoret, mensisipkan, menghapus, ataupun menambah tulisan lain pada isi akta tanpa persetujuan dari para pihak. Yang mana persetujuan tersebut harus dibuktikan dengan adanya paraf dari para pihak di sisi kiri akta pada perubahan isi yang dikehendaki. Tanpa adanya paraf tersebut maka perubahan yang dilakukan oleh notaris dianggap tidak sah, karena merubah isi akta tanpa persetujuan para pihak.

Dalam dunia notaris salah ketik (kata atau kalimat yang salah) sering terjadi,hal tersebut sering dijumpai ketika akta sudah diprint mau ditandatangani, atau ketika notaris sedang melakukan pembacaan akta dihadapan para pihak, atau bisa juga setelah salinan akta dikeluarkan oleh notaris.

Kesalahan ketik dalam akta notaris dapat bersifat Crusial maupun Non Crusial. Kesalahan ketik yang bersifat Non Crusialartinya kesalahan tersebut tidak terlalu penting dan tidak menyebabkan perbedaan makna kata yang kentara dalam substansi akta atau jikapun ada perbedaan makna kata, tetapi secara konteks kalimat tidak dapat ditafsirkan lain dari yang sebenarnya dimaksudkan, 

diantaranya kesalahan dalam ejaan. Misalnya kata "kita" diketik "kata", dan "anggaran dasar" diketik "anggaran datar".

Sebaliknya kesalahan ketik yang bersifat Crusial artinya kesalahan tersebut sangat penting dan bisa berakibat fatal yang bisa mengakibatkan terjadinya perbedaan makna atau perbedaan maksud yang signifikan di dalam substansi akta sehingga substansi akta menjadi tidak sesuai dengan yang sebenarnya ingin dituangkan dalam akta tersebut oleh para penghadap (dalam akta partij) atau oleh notaris (dalam akta reelas). Kesalahan ketik yang substantif ini diantaranya kesalahan penulisan angka dalam jumlah uang, jangka waktu, dan luas objek jual beli, misalnya objek jual beli bangunan seluas " $200 \mathrm{~m}^{2}$ " diketik " $20 \mathrm{~m}^{2}$ " atau "Rp. 100.000,-" diketik "Rp.10.000,-“.

Apabila kesalahan ketik tersebut (pada isi akta), baik yang secara substantif maupun non susbstantif, diketahui sebelum rancangan akta ditandatangani, maka kesalahan tersebut dapat diperbaiki dengan cara melakukan perubahan atau Renvoidan diparaf disebelah kiri akta oleh penghadap, saksi, dan notaris, sebagaimana dimaksud dalam Pasal 48 ayat (2) dan Pasal 50 UUJN.Paraf ini berlakusebagaitandatangansehinggaperubahanisiaktatanpaparafatautandapengesah anlain,mengakibatkanperubahantersebuttidakmengikatpenghadapatauperubahandi anggaptidakadaataubataldemihukum.

Namun apabila kesalahan ketik tersebut baru diketahui setelah salinan akta dikeluarkan maka notaris sebenarnya masih bisa memperbaiki kesalahan ketik tersebut. Menurut pasal 51 ayat (1) dan ayat (2) UUJN pembetulan tersebut dilakukan dengan membuat berita acara pembetulan dan memberikan catatan tentang hal tersebut pada minuta akta asli dengan menyebutkan tanggal dan nomor akta berita acara pembetulan.

Namun pelaksanaan ketentuan Pasal 51 UUJN ini menjadi sulit apabila :

1. Para Penghadap sudah tidak ada lagi di hadapan Notaris, artinya Penghadap sudah meninggalkan Notaris

2. Para Penghadap sulit dihubungi atau bisa dihubungi tapi tidak mau datang dengan berbagai alasan. 

3. Para penghadap sudah tidak mau bertatap muka lagi karena sedang ada sengketa.

Sehingga Akta Berita Acara Pembetulan ini tidak sah jika dilakukan tanpa dihadapan Para Penghadap dan Saksi, artinya jika Para Penghadap tidak bersedia menghadap untuk membuat Berita Acara Pembetulan, maka Notaris tidak bisa berbuat apa-apa hal ini agar notaris memiliki kepastian bahwa para penghadap telah memahami,dan menyetujui pembetulan yang dilakukan oleh notaris, disamping itu melakukan Berita Acara Pembetulan tanpa dihadapan penghadapdan saksi merupakan pelanggaran dan sanksinya sebagaimana tercantum dalam Pasal 51 ayat (4) UUJN.

Dalam hukum perjanjian ada akibat hukum tertentu jika syarat subjektif dan syarat objektif tidak dipenuhi. Jika syarat subjektif tidak terpenuhi, maka perjanjian dapat dibatalkan sepanjang ada permintaan oleh orang-orang tertentu atau yang berkepentingan. Syarat subjektif ini terkadang senantiasa dibayangi ancaman untuk dibatalkan oleh para pihak yang berkepentingan.

Jika syarat objektif tidak dipenuhi, maka perjanjian batal demi hukum, tanpa perlu ada permintaan dari para pihak, dengan demikian perjanjian dianggap tidak pernah ada dan tidak mengikat siapapun

Jika salah satu pihak merasa dirugikan dari akta yang dibuat Notaris, maka pihak yang merasa dirugikan dapat mengajukan gugatan berupa tuntutan gantirugi kepada Notaris yang bersangkutan, dengan kewajiban penggugat, yaitu dalam gugatan harus dapat dibuktikan bahwa kerugian tersebut merupakan akibat langsung dari akta Notaris. Dalam kedua posisi tersebut, penggugat harus dapat membuktikan apa saja yang dilanggar oleh Notaris, dari aspek lahiriah, aspek formal dan aspek materil atas akta Notaris.

Akta Otentik yang dibuat oleh Notaris mempunyai kekuatan pembuktian yang sempurna. Nilai Pembuktian suatu Akta Otentik adalah

1. Lahiriah (uitwendige bewijskracht)

Akta Notaris dengan sendirinya membuktikan keabsahannya sebagai akta otentik (acta publica probant sese ipsa).

2. Formal (formele bewijskracht) 

Akta Notaris dibuat sesuai dengan prosedur yang sudah ditentukan dalam pembuatan akta (Pasal 38 UUJN).

3. Materiil (materiele bewijskracht)

Apa yang tersebut dalam akta merupakan pembuktian yang sah terhadap pihak-pihak yang membuat akta atau mereka yang mendapat hak dan berlaku untuk umum, kecuali ada pembuktian sebaliknya (tegenbewijs).

namun jika dalam pembuatannya menyimpang sesuai dengan pasal 1869 KUH Perdata.

Dimana dalam pasal ini dijelaskan bahwa :

1. Pejabat yang membuat akta tersebut tidak dtentukan oleh undang-undang

2. Pejabat tersebut tidak cakap dalam pembuatannya.

3. Cacat dalam bentuknya

Maka para pihak yang dirugikan bisa menggugat notaris ke pengadilan, hal tersebut sesuai dengan pasal Pasal 84 UUJN. Sebuah akta notariil dapat berakibat batal demi hukum (kebatalan). Kebatalan dibagi menjadi 2 (dua) kelompok, yaitu: kebatalan absolut dan kebatalan relatif

1. Kebatalan absolut adalah bahwa tindakan hukum yang batal itu tidak menimbulkan akibat hukum bagi siapapun, tindakan hukum itu batal bagi siapapun. Jadi tidak ada orang yang terikat pada tindakan hukum seperti itu yang berarti sejak semula tindakan hukum tersebut tidak mempunyai akibat hukum. Yang dimaksud dengan tindakan hukum adalah tindakan-tindakan yang menimbulkan akibat hukum dan akibat hukum itu dikehendaki atau dianggap dikehendaki.

2. Kebatalan Relatif adalah hanya terjadi jika diminta oleh orang-orang tertentu dan hanya berlaku terhadap orang-orang tertentu itu saja. 



\subsection{Tanggung Gugat Notaris Terhadap Akta Otentik Yang Dibuat Oleh Atau Dihadapannya.}

Menurut Kamus Besar Bahasa Indonesia, tanggung gugat mengandung makna dimana seseorang wajib menanggung segala sesuatunya kalau ada sesuatu hal, boleh dituntut, dipersalahkan, diperkarakan, dan sebagainya. ${ }^{13}$

J.H. Nieuwenhuis, berpendapat bahwa tanggung gugat merupakan kewajiban seseorang untuk menanggung ganti kerugian sebagai akibat pelanggaran norma. Perbuatan melanggar norma tersebut dapat terjadi disebabkan karena perbuatan melawan hukum atau wanprestasi. ${ }^{14}$

Salah satu perilaku seorang Notaris dalam menjalankan jabatannya adalah senantiasa bersikap profesional. Menyandang jabatan selaku Notaris harus jujur terhadap diri sendiri yang berlandaskan pada spiritual, moral, mental dan akhlak baik dan benar. Selain mempunyai tingkat intelektual tinggi serta yang mempunyai sifat netral/tidak memihak, independen, mandiri, tidak mengejar materi, menjunjung harkat dan martabat Notaris yang profesional.

Notaris dalam menjalankan jabatannya harus berpedoman dan tunduk kepadaUndang-undang Jabatan Notaris. Yang mana didalam Undang-undang tersebut mengatur hal-hal mengenai kewajiban, dan larangan-larangan yang harus dilaksanakan oleh notaris. Jika dalam melaksanakan tugas dan jabatannya notaris tersebut melakukan kesalahan atau kelalaian maka notaris dapat dikenai sanksi sebagaimana dimuat dalam Pasal 84 UUJN.

Untuk menentukan adanya suatu pertanggungjawaban secara perdata yang dilakukan oleh seorang Notaris maka harus dapat dijabarkan unsur-unsur tersebut, yaitu sebagai berikut :

1. Adanya suatu perbuatan.

Dalam hal ini notaris melakukan perbuatan yaitu membuat kesalahan pengetikan dalam akta.

2. Perbuatan tersebut melanggar hukum.

\footnotetext{
${ }^{13}$ Poerwadarminta, W.J.S., Kamus Umum Bahasa Indonesia, Jakarta, 1976, hlm 1014

${ }^{14}$ J.H.Niuwenhuis, Hoofdstukken Verbintenissenrecht, terjemahan, Universitas Airlangga, Surabaya, 1985, hlm 135
} 

Dalam hal ini notaris telah melakukan suatu perbuatan yang bertentangan dengan kewajiban hukumnya yang juga telah diatur secara tegas dalam undang-undang, yaitu kewajiban untuk bertindak seksama sebagaimana diatur dalam pasal 16 ayat (1) huruf a UUJN

3. Adanya kesalahan dari pihak pelaku

Dalam melakukan kesalahan ketik, terdapat kelalaian pada notaris yang bersangkutan sehingga unsur kesalahan pun terpenuhi

4. Adanya kerugian bagi korban

Dalam hal ini adanya kesalahan ketik pada akta notaris yang bersifat substantif, misalnya kesalahan ketik mengenai tanggal jatuh tempo kredit yang seharusnya tanggal 20 ternyata dalam akta tertulis tanggal 30, hal ini dapat merugikan pihak kreditur karena didalam setiap kredit yang melebihi tanggal jatuh tempo terdapat bunga yang harus dibayar oleh debitur sehingga pihak yang berkepentingan dapat mengalami kerugian secara materiil.

5. Adanya hubungan kausal antara perbuatan dengan kerugian

Kesalahan ketik yang dilakukan oleh notaris misalnya kesalahan ketik mengenai jumlah uang yang harus dibayar / diterima masing-masing pihak, secara logis dapat diperkirakan menyebabkan kerugian bagi pihak yang berkepentingan, sehingga dapat dikatakan bahwa ada hubungan kausal antara kesalahan ketik yang dilakukan oleh notaris dengan kerugian pihak yang berkepentingan.

Ketentuan perundang-undangan dari perbuatan melawan hukum bertujuan untuk melindungi dan memberikan ganti rugi kepada pihak yang dirugikan. Perbedaan perbuatan melawan hukum dan perbuatan pidana menurut Rachmat Setiawan adalah ${ }^{15}$ “Setiap perbuatan pidana selalu dirumuskan secara seksama dalam undang-undang, sehingga sifatnya terbatas. Sebaliknya pada perbuatan melawan hukumadalah tidak demikian. Undang-undang hanya menentukan satu pasal umum, yang memberikan akibat-akibat hukum terhadap perbuatan melawan hukum."

\footnotetext{
${ }^{15}$ Rachmat Setiawan, 1982, Tinjauan Elementer Perbuatan Melawan Hukum, Alumni, Bandung, hlm 15
} 

Sanksi yang diberikan yang diberikan terhadap pertanggungjawaban perdata seorang Notaris yang melakukan perbuatan melawan hukum pembuatan akta otentik adalah sanksi perdata. Sanksi ini berupa penggantian biaya, ganti rugi dan bunga merupakan akibat yang akan diterima Notaris atas tuntutan para penghadap yang merasa dirugikan atas pembuatan akta oleh Notaris. Penggantian biaya, ganti rugi atau bunga harus didasarkan pada suatu hubungan hukum antara Notaris dengan para pihak yang menghadap Notaris. Jika ada pihak yang merasa dirugikan sebagai akibat langsung dari suatu akta Notaris, maka yang bersangkutan dapat menuntut secara perdata terhadap Notaris. Dengan demikian, tuntutan penggantian biaya, ganti rugi dan bunga terhadap Notaris tidak berdasarkan atas penilaian atau kedudukan suatu alat bukti yang berubah karena melanggar ketentuan-ketentuan tertentu, tetapi hanya dapat didasarkan padahubungan hukum yang ada atau yang terjadi antara Notaris dengan para penghadap.

Pasal 41 UUJN juga menentukan adanya sanksi perdata, jika Notaris melakukan perbuatan melawan hukum atau pelanggaran terhadap Pasal 38, Pasal 39, dan Pasal 40 UUJN maka akta Notaris hanya akan mempunyai pembuktian sebagai akta di bawah tangan. Akibat dari akta Notaris yang seperti itu, maka dapat menjadi alasan bagi pihak yang menderita kerugian untuk menuntut penggantian biaya, ganti rugi dan bunga kepada Notaris.

\subsection{Tugas, Fungsi, dan Kewenangan Majelis Kehormatan Notaris}

Berdasarkan Peraturan Menteri Hukum dan Hak Asasi Manusia Republik Indonesia Nomor 7 tahun 2016 (selanjutnya disebut Permenkumham RI), notaris dalam menjalankan jabatannya diawasi dan dibina oleh Majelis Kehormatan Notaris hal tersebut diatur dalam pasal 1 Permenkumham RI. Yang mana susunan Organisasi Majelis Kehormatan Notaris ini diatur dalam Pasal 2 ayat (1), dan Majelis Kehormatan Notaris ini sendiri mempunyai tugas dan fungsi sebagaimana diatur dalam Pasal 17 dan Pasal 18. Sedangkan Majelis Kehormatan Notaris Wilayah juga mempunyai wewenang yang tidak kalah penting dan hal tersebut diatur dalam Pasal 20 Permenkumham RI Nomor 7 tahun 2016. 

Melihat dari semua pemaparan dan penjelasan diatas tentunya peran dari majelis kehormatan notaris baik pusat maupun wilayah sangatlah dibutuhkan oleh notaris.Sebagai pengawasan dan pembinaan notaris, dalam hal ini juga kita dapat mengetahui bahwa jika notaris telah melakukan kesalahan ataupun kelalaian dalam menjalankan jabatannya tentunya para penegak hukum tidak serta merta langsung memanggil notaris yang bersangkutan melainkan harus melalui prosedur yang benar.

Jika kesalahan yang dibuat memang karena atas kelalaian dari notaris maka notaris tersebut bisa untuk dipanggil untuk dimintai keterangan sebagai saksi, namun bila ternyata akta tersebut telah sesuai pembuatannyabaik secara prosedur pembuatan atau secara aturan yang telah ditentukan maka cukup dengan akta saja tidak perlu notaris hadir dalam pemeriksaan, sebab akta notaris tersebut juga bisa merupakan sebuah jawaban atas sengketa yang terjadi.

\section{KESIMPULAN}

Berdasarkan dari hasil penelitian dan pembahasan diatas, maka dapat ditarik kesimpulan sebagai berikut bahwa :

1. Dampak hukum atas perjanjian kredit yang dibuat karena adanya kesalahan ketik notaris dalam pembuatannya terhadap para pihak adalah hilangnya keotentikkan atau terdegradasinya akta tersebut.

2. Notaris dapat dikenakan sanksi tanggung gugat atas keteledorannya dalam membuat akta yaitu berupa penggantian biaya, ganti rugi, dan bungaterhadap pihak yang dirugikan.

3. Peran dari Majelis Kehormatan Notaris sangatlah penting untuk menjaga nama baik profesi notaris dan untuk memberi arahan kepada notaris agar notaris tidak terjerumus kedalam urusan pidana maupun perdata. 


\section{DAFTAR PUSTAKA}

\section{Buku :}

Munir Fuady, Perbuatan Melawan Hukum, cet.1, Citra Aditya Bakti, Bandung, 2002, hlm.3

G.H.S. Lumban Tobing, Peraturan Jabatan Notaris, Cetakan ke-5, Jakarta : Erlangga, hlm. 51-52

Habib Adjie. 2009. Hukum Notaris Indonesia Tafsir Tematik Terhadap UU no.30 tahun 2004 Tentang Jabatan Notaris, cet. Kedua. Bandung: PT Refika Aditama. hlm. 77

Johnny Ibrahim, Teori dan Metodologi Penelitian Hukum Normatif, Cet.3, Bayumedia, Malang, 2010, hlm.93

J.H.Niuwenhuis, Hoofdstukken Verbintenissenrecht, terjemahan, Universitas Airlangga, Surabaya, 1985, hlm 135

Peter Mahmud Marzuki, Penelitian Hukum, Cet. 6, Kencana Prenada Media Group, Jakarta, 2010, hlm.35

Poerwadarminta, W.J.S., Kamus Umum Bahasa Indonesia, Jakarta, 1976, hlm 1014

Rachmat Setiawan, 1982, Tinjauan Elementer Perbuatan Melawan Hukum, Alumni, Bandung, hlm 15

Ridwan HR. 2006. Hukum Administrasi Negara. Jakarta : Raja Grafindo Persada. hlm.79

Sutan Remi Sjahdeini, Kebebasan Berkontrak dan Perlindungan yang Seimbang bagi Para Pihak dalam Perjanjian Kredit Bank di Indonesia, Cetakan I, Institut Bankir Indonesia, Jakarta, 1993, hlm. 2-3

Suhardjono, Sekilas Tinjauan Akta Menurut Hukum, Varia Peradilan, Nomor 123, 1995, hlm.133-135

Setiawan Wawan, Hak Ingkar dari Notaris dan Hubungannya dengan KUHAP (suatu kajian uraian yang disajikan dalam konggress INI di Jakarta, 1995), hlm. 2 